\title{
Italian Ryegrass (Lolium perenne ssp. multiflorum) and Corn (Zea mays) Competition
}

\author{
Vijay K. Nandula \\ US Department of Agriculture-Agricultural Research Service (USDA-ARS), Crop Production Systems Research \\ Unit, Stoneville, USA \\ Email: vijay.nandula@ars.usda.gov
}

Received 7 November 2014; revised 2 December 2014; accepted 14 December 2014

Copyright (c) 2014 by author and Scientific Research Publishing Inc.

This work is licensed under the Creative Commons Attribution International License (CC BY). http://creativecommons.org/licenses/by/4.0/

C. (i) Open Access

\section{Abstract}

Italian ryegrass is an annual/biennial grass that is typically used as a pasture crop or a cover crop along roadsides, rights-of-way, and industrial areas. Glyphosate-resistant (GR) Italian ryegrass populations have been documented around the world, mostly in orchard and vineyard situations. The first evidence of evolved GR Italian ryegrass in row/agronomic crops was reported from Washington County, Mississippi in 2005. GR Italian ryegrass populations can jeopardize preplant burndown options in reduced-tillage crop production systems, thereby, delaying planting operations. The effects of competition of Italian ryegrass on crop growth and yield are poorly understood. A field study was conducted in the $\mathbf{2 0 1 2}$ growing season and repeated in the 2013 growing season. GR and susceptible (GS) Italian ryegrass populations were established in the greenhouse and transplanted in prepared corn row beds in the fall of 2011 and 2012 at $0,1,2,3$, and 4 plants.meter-1 of crop row. Italian ryegrass plants overwintered and developed over the following spring-summer. Glyphosate was applied at $1.26 \mathrm{~kg} \cdot \mathrm{ae} / \mathrm{ha}(1.5 \times$ of labeled rate $)$ in the spring to burndown the Italian ryegrass plants and corn was planted into the ryegrass residue 2 - 3 wk later. Current corn production practices were followed. Corn density (early and late season), height (early season), and yield and Italian ryegrass biomass (early-mid season) measurements were recorded during both years. Corn height was greater in 2012 than that in 2013 at comparable stages of the growing season, due to a cooler and wetter early season in 2013 than that in 2012. Averaged across weed densities, corn density (both early and late season) and yield were higher in the GS than those in the GR population, but Italian ryegrass biomass was similar for both populations. Averaged across Italian ryegrass populations, corn density (both early and late season), and yield were inversely proportional to Italian ryegrass density. In summary, Italian ryegrass significantly reduced corn density and yield and reduction was greater with the GR than that with the GS population. Studies are underway to study inter population competition in Italian ryegrass and 
investigate allelopathic effects of Italian ryegrass on selected crops.

Keywords

Competition, Corn, Interference, Italian Ryegrass, Lolium perenne ssp. multiflorum (Lam.) Husnot, Zea mays L.

\section{Introduction}

Italian ryegrass is an annual/biennial grass that can germinate, emerge, and establish over a range of environmental conditions [1] [2]. Annual ryegrass (Lolium spp.) is typically used as a pasture crop or a cover crop along roadsides, rights-of-way, and industrial areas [1] [3]. Italian ryegrass has become established along roadsides due to its ability to hybridize with cultivated annual ryegrass species, escape cultivation, and possessing a network of broad and shallow fibrous root system [4]-[8].

Italian ryegrass has developed in to an economically important weed affecting small grain and vegetable crops [9]-[11]. For example, winter wheat yield was decreased by $4700 \mathrm{~kg} \cdot \mathrm{ha}^{-1}$ when Italian ryegrass density increased from 0.7 to 3 plants $\cdot \mathrm{m}^{-2}$ [9]. Italian ryegrass densities of 600 to 1000 plants $\cdot \mathrm{m}^{-2}$ caused $100 \%$ yield loss in broccoli (Brassica oleracea var. botrytis L.) [10]. Competition from Italian ryegrass reduced winter wheat (Triticum aestivum L.) yield up to 92\% [11].

Corn is an economically important crop in Mississippi. It is the first of the spring planted crops. Hence it is prone to competition from established weeds such as Italian ryegrass, especially, glyphosate-resistant populations.

Control of Italian ryegrass has traditionally been realized by chemical means [1]. Relentless selection pressure from herbicides has resulted in the evolution of resistance in Italian ryegrass to several herbicide mechanisms of action across varied cropping systems and many countries [12], thereby, making management difficult. Resistance to acetolactate synthase inhibiting herbicides in certain Italian ryegrass populations from Mississippi in 1996, Arkansas, Georgia, and Idaho was reported [12] [13]. Historically, glyphosate was frequently in use for controlling Italian ryegrass and other weed flora in orchards and vineyards. Original reports of GR Italian ryegrass were from orchard situations in Chile in 2003 [14] and Oregon in 2005 [15].

In agronomic cropping areas across the US, including Mississippi, glyphosate was used as a preplant burndown and/or post-harvest cleanup treatment, prior to the commercialization of glyphosate resistant (GR) crops in the mid 1990s. With widespread adoption of the GR crops, multiple in-season postemergence applications of glyphosate have become common practice. This added selection pressure from glyphosate resulted in Italian ryegrass populations exhibiting increasingly less susceptibility. The first evidence of evolved GR Italian ryegrass in row/agronomic crops was reported from Washington County, Mississippi in 2005 [16]. Currently, 32 counties of the state contain GR Italian ryegrass [1]. States neighboring Mississippi such as Arkansas, Louisiana, and Tennessee and other states, North Carolina and California (non row crop), have confirmed cases of GR Italian ryegrass [12].

GR Italian ryegrass populations can seriously jeopardize preplant burndown options in reduced-tillage crop production systems, thereby, delaying planting operations. A plausible reason for the proliferation of GR Italian ryegrass in the midsouthern US (Mississippi, Arkansas, Tennessee) could be the concentration of resources towards tackling the much broader problem of GR Palmer amaranth (Amaranthus palmeri S.Wats.). GR Italian ryegrass has the potential to affect multiple row crops such as corn, cotton (Gossypium hirsutum L.), rice (Oryza sativa L.), soybean (Glycine max Merr.), and wheat. The effects of competition and interference from Italian ryegrass on crop growth and yield are poorly understood. Therefore, a field study was conducted to determine the impact of GR Italian ryegrass competition on the growth and yield of corn.

\section{Materials and Methods}

\subsection{Rationale for Glyphosate Treatment on Italian Ryegrass}

This research was conducted to strike a balance between a "scientific/academic" study and a "real world" sce- 
nario mimicking a grower's field. The information generated by this research is expected to provide an estimate of real damage done to a crop from Italian ryegrass, especially GR, when its management is ignored or neglected with continued belief in the effectiveness of glyphosate.

\subsection{Study Design}

Italian ryegrass has a biennial growth habit, in that, it completes its life cycle over two growing seasons. In general, it germinates in the fall, overwinters, grows vigorously early in the following spring, and produces seed by early summer. A spring germination and emergence flush occurs, but it is the fall emerging plants that are more robust and competitive at the time of preplant field operations in the spring.

A two-year field study was initiated in fall 2011, followed by 2012, by transplanting 6-week-old (15-cm tall, 4- to 5-leaf stage with at least 3 tillers) GR and glyphosate susceptible (GS) [16] Italian ryegrass plants in to 5 -cm diameter by $10-\mathrm{cm}$ deep soil core holes created with a hand-held soil sampler on 100-cm wide crop seed beds to simulate fall emerged plants, such that plants establish in the middle of crop row. GR and GS seedlings were generated as described before [16]. Transplanted seedlings were adequately watered through timely furrow irrigations until the first frost ( November 15). Crop seed beds were prepared on a relatively weed free Dundee silt loam (fine-silty mixed, thermic Aeric Ochraqualf; soil textural fractions of $26 \%$ sand, $55 \%$ silt, and $19 \%$ clay; $\mathrm{pH}$ 6.3, $9.0 \mathrm{~g} \cdot \mathrm{kg}^{-1}$ organic carbon, a CEC of $15 \mathrm{cmol}^{+} \cdot \mathrm{kg}^{-1}$ ) by commonly used procedures of disking, subsoiling, disking, and bedding [17] in the fall of 2011 and 2012.

S-metolachlor (Dual Magnum II, Syngenta Crop Protection, Greensboro, NC) was applied at $1.12 \mathrm{~kg} \cdot \mathrm{ai} \cdot \mathrm{ha}^{-1}$ 12 and 22 days prior to transplanting in 2011 and 2012, respectively. GR and GS Italian ryegrass populations were transplanted at $0,1,2,3$, and 4 plants $\mathrm{m}^{-1}$ of corn row. Plot size was $4 \mathrm{~m}$ by $10 \mathrm{~m}$ comprising of 4 corn rows with a row spacing of $100 \mathrm{~cm}$. Glyphosate (Roundup Weather MAX, Monsanto Co., St. Louis, MO) was applied at $1.26 \mathrm{~kg} \cdot \mathrm{ae} \cdot \mathrm{ha}^{-1}(1.5 \times)$ on March 7 during both 2012 and 2013 when Italian ryegrass plants were at least $30 \mathrm{~cm}$ tall as a "rescue" treatment.

Corn (Pioneer 33N55 RR, Pioneer Hi-Bred International, Johnston, IA) was planted at a density of 74,000 plants ha $^{-1}$ in Italian ryegrass residue on March 26, 2012 and March 20, 2013, corresponding to 19 and 13 days after glyphosate application in 2012 and 2013, respectively. S-metolachlor at $1.43 \mathrm{~kg} \cdot \mathrm{ha}^{-1}$ and atrazine at 0.84 $\mathrm{kg} \cdot \mathrm{ai} \cdot \mathrm{ha}^{-1}$ were applied on the same day of planting during both 2012 and 2013.

\subsection{Crop and Weed Parameters}

The following crop and weed parameters were measured: corn stand counts were recorded from randomly selected 1-m plot lengths, one each from the center two rows for each plot (early-middle season on May 8 in 2012 and May 29 in 2013; late season on August 6 in 2012 and August 26 in 2013); height of 10 randomly selected corn plants from each of the center two rows in each plot (early-middle season on May 8 in 2012 and May 29 in 2013) with a pre-marked measuring stick custom made from PVC tubing; corn yield from the whole plot comprising 4 rows with a combine; and Italian ryegrass above ground biomass from a $0.5 \mathrm{~m}^{2}$ quadrat from each of the center two rows in each plot and dried for 12 weeks in a greenhouse set to ambient conditions (middle season on May 23 in 2012 and May 28 in 2013).

\subsection{Statistical Analysis}

Field studies were setup in a randomized complete block design with 3 replications per treatment each year. Data were analyzed by ANOVA via the PROC GLM statement using SAS software (version 9.2, SAS Institute, Inc., Cary, NC 27513). Linear and non linear regression was used to relate response of dependent variables (corn height, density, and yield, and Italian ryegrass biomass) to Italian ryegrass density. Data were pooled for variables where a significant year effect was not observed. Raw data, despite data duplication, is presented to help readers visualize specific responses.

\section{Results and Discussion}

\subsection{Corn Density-Early Season}

There was no effect of year on influence of Italian ryegrass on corn density in the early part of the season. Therefore, data were combined across years. The decline in corn density with increasing Italian ryegrass density 
followed a linear pattern, best represented by an equation of the form $\mathrm{y}=\mathrm{a}-\mathrm{bx}$, where $\mathrm{y}, \mathrm{a}, \mathrm{b}$, and $\mathrm{x}$ are corn density, an intercept, slope, and Italian ryegrass density (plants $\cdot \mathrm{m}^{-1}$ ), respectively (Figure 1). There was a significant impact of Italian ryegrass population and Italian ryegrass density on corn stand (Table 1). At each Italian ryegrass density, the GR population caused a higher reduction in corn density than the GS population. A significant year by population interaction was observed (Table 1), which could be attributed to a greater reduction in corn density in 2013 (44\% to 72\% of no Italian ryegrass check) than 2012 (9\% to 64\% of no Italian ryegrass check) by the GR population (Table 2).

\subsection{Corn Density—Late Season}

There was no effect of year on influence of Italian ryegrass on corn density late in the season. Therefore, data were combined across years. The decline in corn density with increasing Italian ryegrass density was best represented by a quadratic equation of the form $\mathrm{y}=\mathrm{c}+\mathrm{bx}-\mathrm{ax}^{2}$, where, where $\mathrm{y}, \mathrm{c}, \mathrm{b}$, a, and $\mathrm{x}$ are corn density, a constant, linear coefficient, quadratic coefficient, and Italian ryegrass density, respectively (Figure 2). There was a significant impact of Italian ryegrass population and Italian ryegrass density on late season corn stand (Table 1). As with the early season corn density, late season corn stand tended to be lower at each GR Italian

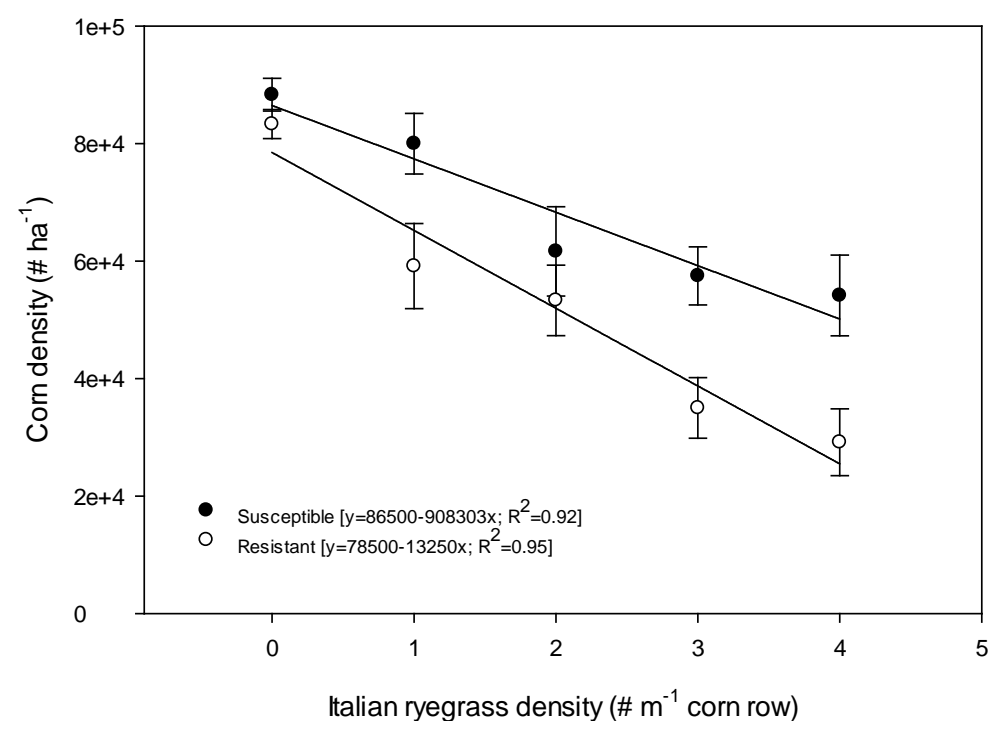

Figure 1. Influence of glyphosate-resistant and -susceptible Italian ryegrass populations on early season corn density in 2012 and 2013 combined.

Table 1. Summary of ANOVA analysis of main and interaction effects on response variables measured in a field study investigating competition between Italian ryegrass and corn.

\begin{tabular}{|c|c|c|c|c|c|}
\hline & \multicolumn{5}{|c|}{ Response variable } \\
\hline & \multicolumn{2}{|c|}{ Corn density } & \multirow[t]{2}{*}{ Corn height } & \multirow[t]{2}{*}{ Italian ryegrass biomass } & \multirow[t]{2}{*}{ Corn yield } \\
\hline & Early season & Late season & & & \\
\hline \multicolumn{6}{|l|}{ Main/Interaction effect } \\
\hline & \multicolumn{5}{|c|}{$\mathrm{P}_{\text {value }}^{\mathrm{a}}$} \\
\hline Year & 0.4618 & 0.9791 & $<0.0001$ & 0.0911 & 0.0344 \\
\hline Population (Pop) & $<0.0001$ & $<0.0001$ & $<0.0001$ & 0.3768 & $<0.0001$ \\
\hline Italian ryegrass density (Den) & $<0.0001$ & $<0.0001$ & $<0.0001$ & $<0.0001$ & $<0.0001$ \\
\hline Year $\times$ Pop & 0.0021 & 0.0274 & 0.1174 & 0.0298 & 0.0003 \\
\hline Year $\times$ Den & 0.3229 & 0.0095 & $<0.0001$ & $<0.0001$ & 0.5607 \\
\hline Pop $\times$ Den & 0.1802 & 0.0351 & 0.0833 & 0.5752 & 0.7781 \\
\hline Year $\times$ Pop $\times$ Den & 0.1042 & 0.5557 & 0.3487 & 0.7113 & 0.9444 \\
\hline
\end{tabular}

${ }^{\mathrm{a}}$ Indicates significance of main or interaction effect at a 95\% level of probability, i.e., at a minimum $\mathrm{P}$ value of 0.0500 . 
Table 2. Response variables measured in a field study investigating competition between Italian ryegrass and $\operatorname{corn}^{\mathrm{a}}$.

\begin{tabular}{|c|c|c|c|c|c|c|c|}
\hline & & & \multicolumn{5}{|c|}{ Response variable } \\
\hline & & & \multicolumn{2}{|c|}{ Corn density } & \multirow[t]{2}{*}{ Corn height } & \multirow[t]{2}{*}{ Italian ryegrass biomass } & \multirow[t]{2}{*}{ Corn yield } \\
\hline & & & Early season & Late season & & & \\
\hline \multirow[t]{2}{*}{ Year } & Population & Density & & & & & \\
\hline & & $\# \mathrm{~m}^{-1}$ corn row & $\# \mathrm{ha}^{-1}$ & $\# \mathrm{ha}^{-1}$ & $\mathrm{~cm}$ & $\mathrm{~kg} \cdot \mathrm{ha}^{-1}$ & $\mathrm{~kg} \cdot \mathrm{ha}^{-1}$ \\
\hline \multirow[t]{10}{*}{2012} & GR & 0 & 78,333 & 63,333 & 127 & - & 13,354 \\
\hline & & 1 & 71,667 & 63,333 & 89 & 68,695 & 10,989 \\
\hline & & 2 & 56,667 & 63,333 & 65 & 104,966 & 9599 \\
\hline & & 3 & 45,000 & 52,500 & 56 & 72,775 & 7329 \\
\hline & & 4 & 28,333 & 35,000 & 56 & 88,596 & 5384 \\
\hline & GS & 0 & 83,333 & 62,500 & 127 & - & 14,383 \\
\hline & & 1 & 70,000 & 68333 & 09 & 100,603 & 10,855 \\
\hline & & 2 & 48,333 & 69,167 & 70 & 80,660 & 9691 \\
\hline & & 3 & 55,000 & 75,000 & 60 & 85,905 & 9541 \\
\hline & & 4 & 53,333 & 55,000 & 68 & 98,322 & 7372 \\
\hline \multirow[t]{10}{*}{2013} & GR & 0 & 88,333 & 85,000 & 70 & - & 10,862 \\
\hline & & 1 & 46,667 & 47,500 & 48 & 47,923 & 8892 \\
\hline & & 2 & 50,000 & 48,333 & 44 & 101,453 & 7783 \\
\hline & & 3 & 25,000 & 25,833 & 39 & 134,338 & 6058 \\
\hline & & 4 & 30,000 & 34,167 & 41 & 179602 & 6822 \\
\hline & GS & 0 & 93,333 & 83,333 & 70 & - & 19,566 \\
\hline & & 1 & 90,000 & 80,833 & 64 & 38,173 & 13,703 \\
\hline & & 2 & 75,000 & 76,667 & 63 & 70,487 & 14,006 \\
\hline & & 3 & 60,000 & 66,667 & 58 & 110,726 & 12,506 \\
\hline & & 4 & 55,000 & 58,333 & 70 & 138,728 & 13,712 \\
\hline
\end{tabular}

${ }^{\mathrm{a}}$ Details in the text. GR, glyphosate-resistant; GS, glyphosate-susceptible.

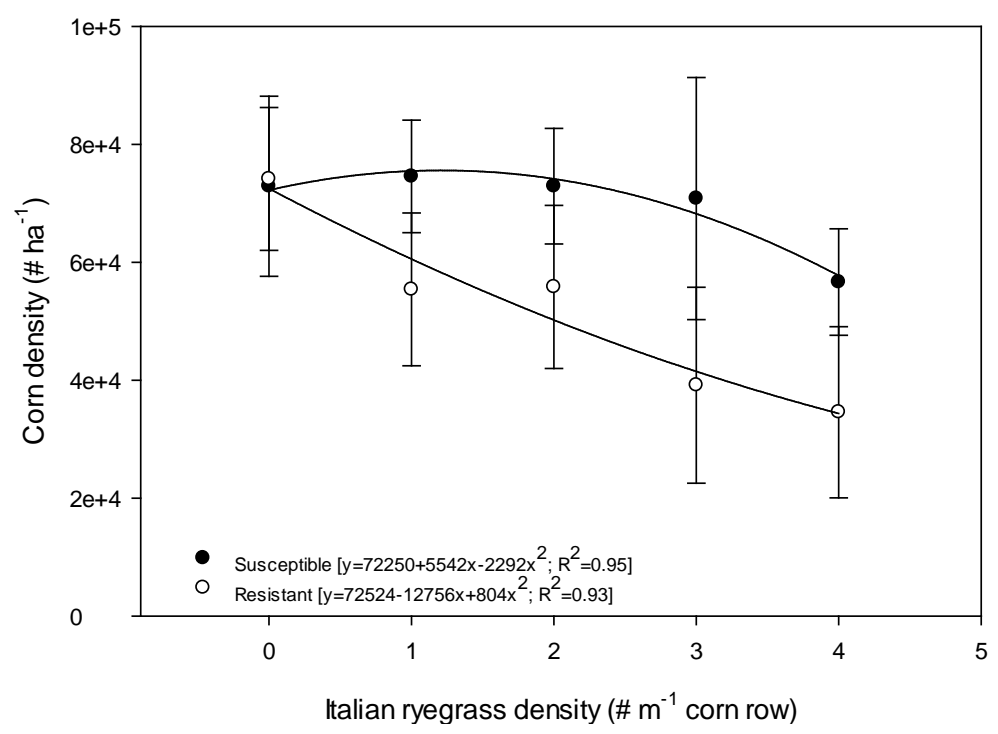

Figure 2. Influence of glyphosate-resistant and -susceptible Italian ryegrass populations on late season corn density in 2012 and 2013 combined.

ryegrass density compared to the corn density at corresponding GS density. Significant year by population, year by Italian ryegrass density, and population by Italian ryegrass density interactions were observed with late sea- 
son corn density (Table 1). The year by population interaction was a result of higher corn density in GS plots in 2013 than 2012 and vice versa for the R plots. The year by Italian ryegrass density interaction was due to lower corn density in 2013 compared to 2012. The population by Italian ryegrass density interaction was attributable to greater decrease in corn density from GR (up to $54 \%$ of no Italian ryegrass check) competition than from GS ( $28 \%$ of no Italian ryegrass check) (Table 2 ).

\subsection{Corn Height-Early Season}

There was a significant effect of year on influence of Italian ryegrass on corn height in the early part of the season. Therefore, data were separated by year. In general, corn height was lower in 2013 than 2012 due to crop injury from S-metolachlor brought about by the cooler and wet conditions in 2013 (Table 3). The decline in corn height with increasing Italian ryegrass density was best represented by a sigmoidal logistic three parameter equation of the form $y=a /\left(1+a b s\left(x / x_{0}\right)^{b}\right)$, where $y, a, x, x_{0}$, and $b$ are corn density, an intercept, Italian ryegrass density, asymptote, and slope, respectively (Figure 3 and Figure 4). There was a significant impact of population, Italian ryegrass density, and year by Italian ryegrass density interaction on corn height (Table 1). Corn height was higher in the GS plots $(75.3 \mathrm{~cm})$ than the GR plots $(63.4 \mathrm{~cm})$ (Table 2). Italian ryegrass densities had the following influence on corn height: $0(98.6 \mathrm{~cm})>1(77.7 \mathrm{~cm})>2(60.5 \mathrm{~cm})=4(55.6 \mathrm{~cm})=3(54.4 \mathrm{~cm})$ (Table 2). The year by Italian ryegrass interactive effect on early season corn height was because of a larger reduction of corn height in 2012 (up to 52\% of no Italian ryegrass check) than 2013 (up to 30\% of no Italian ryegrass check) due to ryegrass interference (Table 2).

Table 3. Weather parameters at Stoneville, MS in 2011, 2012, and 2013.

\begin{tabular}{|c|c|c|c|c|}
\hline \multirow[b]{2}{*}{ Year } & \multirow[b]{2}{*}{ Month } & \multicolumn{2}{|c|}{ Average air temperature } & \multirow[t]{2}{*}{ Precipitatior } \\
\hline & & Low & High & \\
\hline & & \multicolumn{2}{|c|}{${ }^{\circ} \mathrm{C}$} & $\mathrm{mm}$ \\
\hline \multirow[t]{3}{*}{2011} & October & 9.9 & 24.9 & 0.87 \\
\hline & November & 7.7 & 19.7 & 3.75 \\
\hline & December & 3.0 & 12.1 & 7.42 \\
\hline \multirow[t]{12}{*}{2012} & January & 3.3 & 15.9 & 2.27 \\
\hline & February & 5.1 & 15.2 & 2.74 \\
\hline & March & 12.9 & 24.3 & 4.87 \\
\hline & April & 13.8 & 25.8 & 3.55 \\
\hline & May & 19.0 & 30.9 & 1.66 \\
\hline & June & 20.4 & 31.7 & 5.41 \\
\hline & July & 23.5 & 33.9 & 3.74 \\
\hline & August & 21.1 & 33.8 & 3.52 \\
\hline & September & 17.8 & 30.8 & 2.76 \\
\hline & October & 10.0 & 21.5 & 4.74 \\
\hline & November & 5.4 & 18.4 & 0.80 \\
\hline & December & 5.9 & 15.6 & 4.03 \\
\hline \multirow[t]{9}{*}{2013} & January & 3.5 & 12.6 & 8.41 \\
\hline & February & 3.6 & 13.8 & 4.75 \\
\hline & March & 4.4 & 15.8 & 3.14 \\
\hline & April & 10.4 & 22.3 & 5.58 \\
\hline & May & 15.7 & 26.2 & 4.67 \\
\hline & June & 21.0 & 30.4 & 3.09 \\
\hline & July & 20.4 & 31.5 & 1.56 \\
\hline & August & 21.3 & 33.8 & 1.63 \\
\hline & September & 18.8 & 32.3 & 4.33 \\
\hline
\end{tabular}




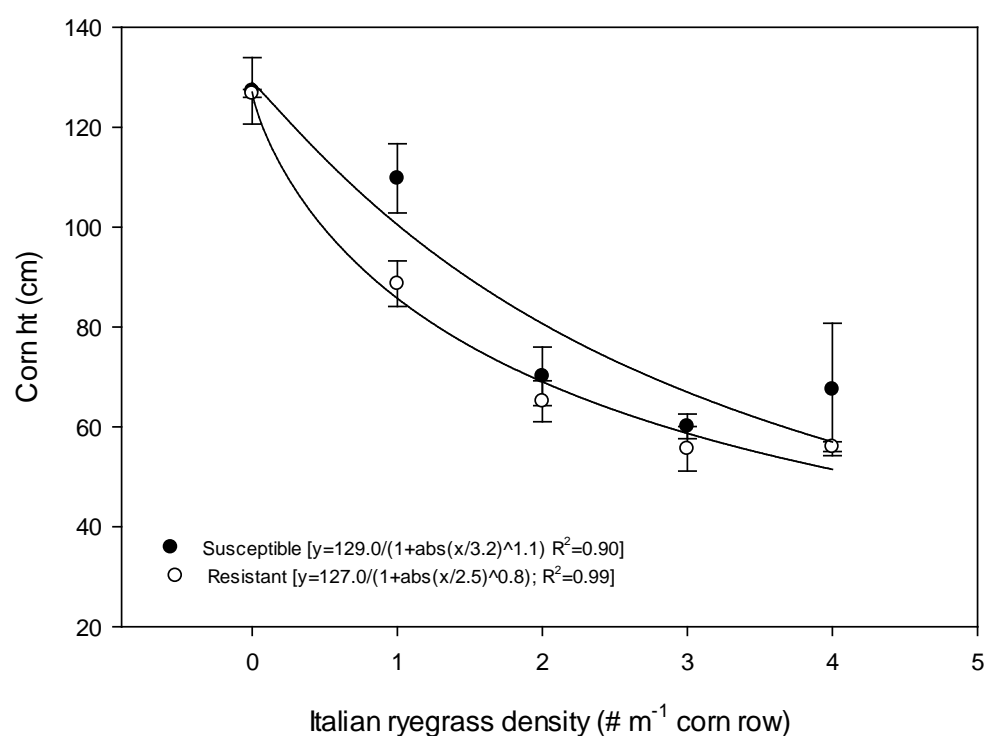

Figure 3. Influence of glyphosate-resistant and -susceptible Italian ryegrass populations on corn height in 2012.

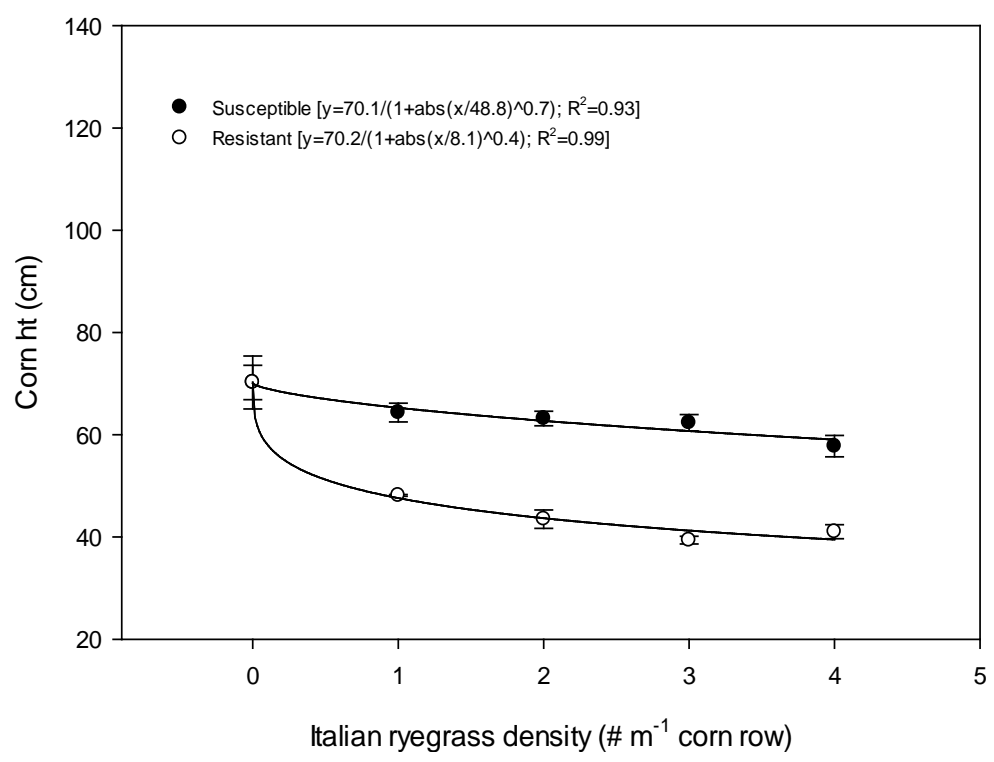

Figure 4. Influence of glyphosate-resistant and -susceptible Italian ryegrass populations on corn height in 2013.

\subsection{Italian Ryegrass Biomass—Middle Season}

There was no effect of year on influence of Italian ryegrass density on Italian ryegrass biomass in middle part of the season. Therefore, data was combined across years. The increase in Italian ryegrass biomass with increasing Italian ryegrass density followed a linear pattern, best represented by an equation of the form $\mathrm{y}=\mathrm{a}+\mathrm{bx}$, where $\mathrm{y}$, $\mathrm{a}, \mathrm{b}$, and $\mathrm{x}$ are Italian ryegrass biomass, an intercept, slope, and Italian ryegrass density, respectively (Figure 5). There was a significant impact of Italian ryegrass density, and year by population and year by Italian ryegrass density interactions on Italian ryegrass biomass (Table 1). The number of Italian ryegrass plants per $\mathrm{m}$ of corn row had the following influence on the weed biomass: $4\left(125,062 \mathrm{~kg}^{-h^{-1}}\right)>3\left(100,936 \mathrm{~kg} \cdot \mathrm{ha}^{-1}\right)=2(91,879$ $\left.\mathrm{kg} \cdot \mathrm{ha}^{-1}\right)>1\left(63,849 \mathrm{~kg} \cdot \mathrm{ha}^{-1}\right)$ (Table 2). Italian ryegrass biomass was higher by $4 \%$ in 2012 than 2013 in the GS plots, but lower in the GR plots by 29\% in 2012 compared to 2013 (Table 2). Italian ryegrass biomass was higher in 2012 than 2013 at 1 and 2 plants per m of corn row density, but lower at 3 and 4 plants per $m$ of crop 


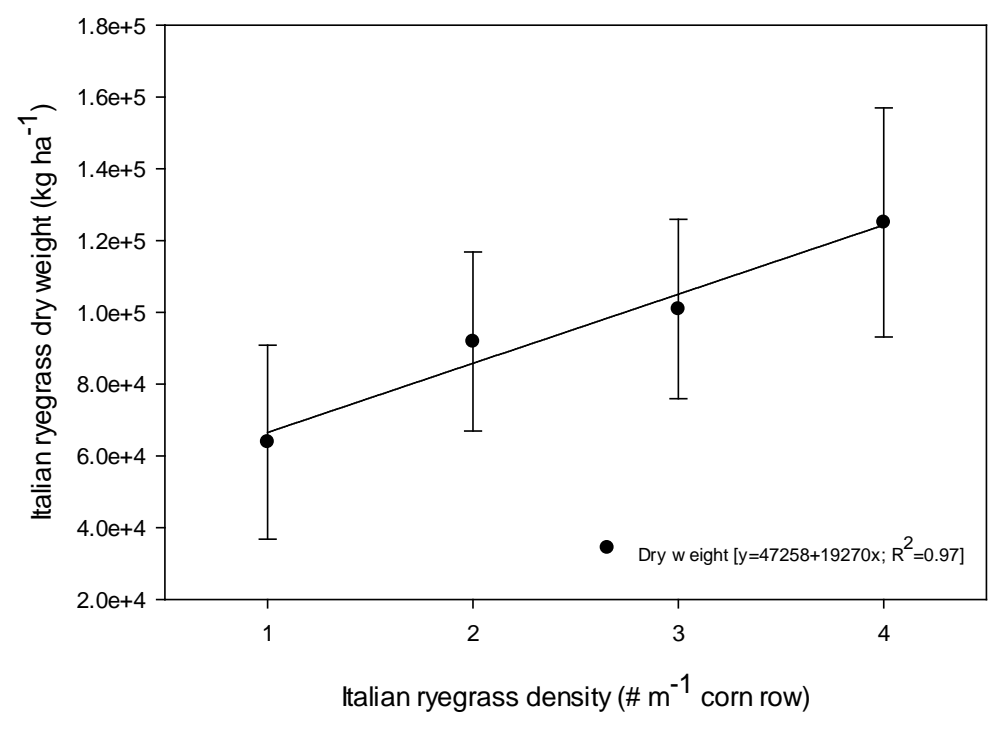

Figure 5. Relationship of Italian ryegrass density and biomass accumulation in 2012 and 2013 combined.

row, resulting in a year by weed density interaction (Table 2).

\subsection{Corn Yield}

There was a significant year effect on influence of Italian ryegrass on corn yield. Therefore, data were separated by year. The decline in corn density with increasing Italian ryegrass density in 2012 followed a linear pattern, best represented by an equation of the form $\mathrm{y}=\mathrm{a}-\mathrm{bx}$, where $\mathrm{y}$, $\mathrm{a}, \mathrm{b}$, and $\mathrm{x}$ are corn yield, an intercept, slope, and Italian ryegrass density, respectively (Figure 6); the pattern in 2013 was a quadratic response of the form y $=\mathrm{c}-\mathrm{bx}+\mathrm{ax}^{2}$, where, where $\mathrm{y}, \mathrm{c}, \mathrm{b}, \mathrm{a}$, and $\mathrm{x}$ are corn yield, a constant, linear coefficient, quadratic coefficient, and Italian ryegrass density, respectively (Figure 7). There was a significant impact of population, Italian ryegrass density, and year by population interaction on corn yield (Table 1). Corn yield was higher in the GS plots $\left(12,533 \mathrm{~kg} \cdot \mathrm{ha}^{-1}\right)$ than the GR plots $\left(8707 \mathrm{~kg} \cdot \mathrm{ha}^{-1}\right)$ (Table 2). Among Italian ryegrass densities, the following pattern of influence on corn yield was apparent: $0\left(14,541 \mathrm{~kg} \cdot \mathrm{ha}^{-1}\right)>1\left(11,110 \mathrm{~kg} \cdot \mathrm{ha}^{-1}\right) \geq 2\left(10,270 \mathrm{~kg} \cdot \mathrm{ha}^{-1}\right)=3$ $\left(8858 \mathrm{~kg} \cdot \mathrm{ha}^{-1}\right)=4\left(8323 \mathrm{~kg} \cdot \mathrm{ha}^{-1}\right)$ (Table 2). Corn yield was higher in $2013\left(14,698 \mathrm{~kg} \cdot \mathrm{ha}^{-1}\right) \mathrm{vs.} 2012(10,368$ $\left.\mathrm{kg} \cdot \mathrm{ha}^{-1}\right)$ in GS plots, but vice versa in the GR plots (9331 kg·ha ${ }^{-1}$ in $2012 \mathrm{vs.} 8084 \mathrm{~kg} \cdot \mathrm{ha}^{-1}$ in 2013) (Table 2).

The above results strongly support observations made recently [1] that dense stands of GR Italian ryegrass pose spring burn down challenges and soon to follow crop establishment in the mid southern United States. Corn density (early and late season) and height were both affected by Italian ryegrass density. There is very little information on the impact of Italian ryegrass competition on vegetative growth stages of crops. Italian ryegrass leaf area indices were higher than winter wheat at booting stage by $68 \%$, thereby, reducing the photo synthetically active radiation available to wheat [11]. Winter wheat was a stronger competitor during vegetative stages, whereas Italian ryegrass was stronger in the reproductive stages. Thinner and fibrous roots of Italian ryegrass provide greater competitive edge over wheat [18].

Italian ryegrass has traditionally been associated with winter wheat, and hence, most reports on its influence on yield have been on this crop. Winter wheat grain yield was decreased from interference from Italian ryegrass amounting to $4100 \mathrm{~kg} \cdot \mathrm{ha}^{-1}$ when the weed density increased from 0.7 to 93 plants $\cdot \mathrm{m}^{-2}$ [9]. Yield reduction was higher in shorter wheat cultivars. A greater yield reduction was recorded at higher nitrogen rates (168 vs 56 $\mathrm{kg} \cdot \mathrm{ha}^{-1}$ ) when Italian ryegrass densities were high [9]. Ability of Italian ryegrass to compete with wheat under limiting conditions of phosphorus was attributed to the weed's larger root surface area [19]. Wheat grain yield was decreased by $33 \%$ with 9 weed plants per 100 wheat plants in a $\mathrm{m}^{2}$ [11], by $4.2 \%$ for every 10 Italian ryegrass plants $\cdot \mathrm{m}^{-2}$ [20], and by $38 \%$ with Italian ryegrass at a density of 20 plants $\cdot \mathrm{m}^{-2}$ [21].

Italian ryegrass densities of 600 to 1000 plants $\mathrm{m}^{-1}$ of broccoli row caused $100 \%$ yield loss [10]. Italian ryegrass shading decreased corn yield under minimum tillage conditions [22]. Our results indicate severe yield loss 


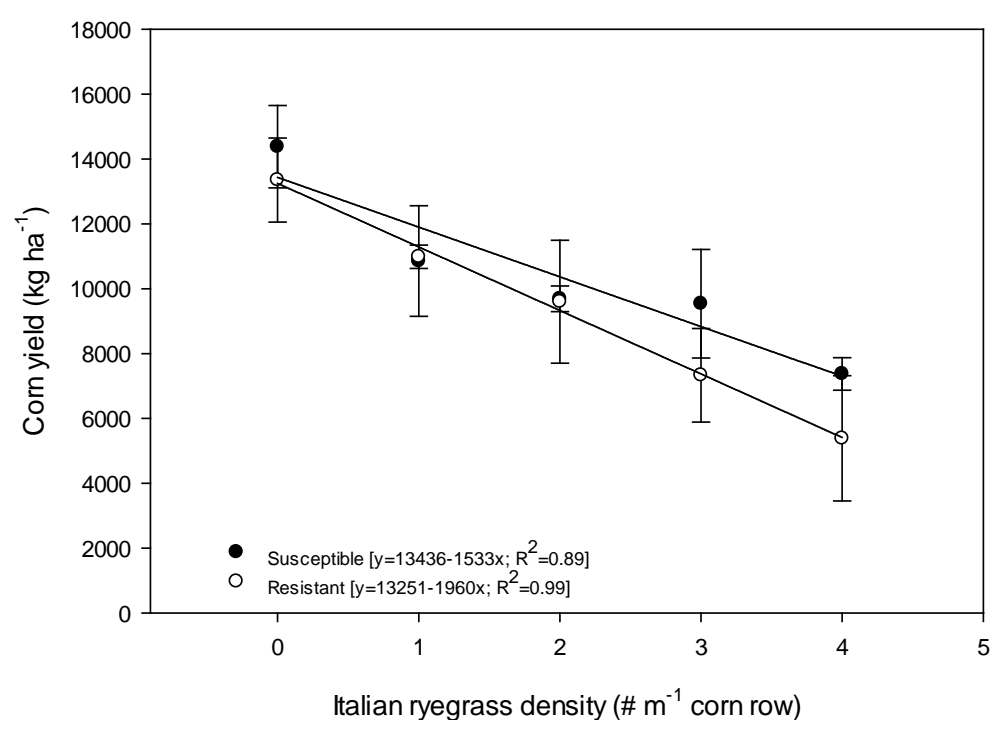

Figure 6. Influence of glyphosate-resistant and -susceptible Italian ryegrass populations on corn yield in 2012.

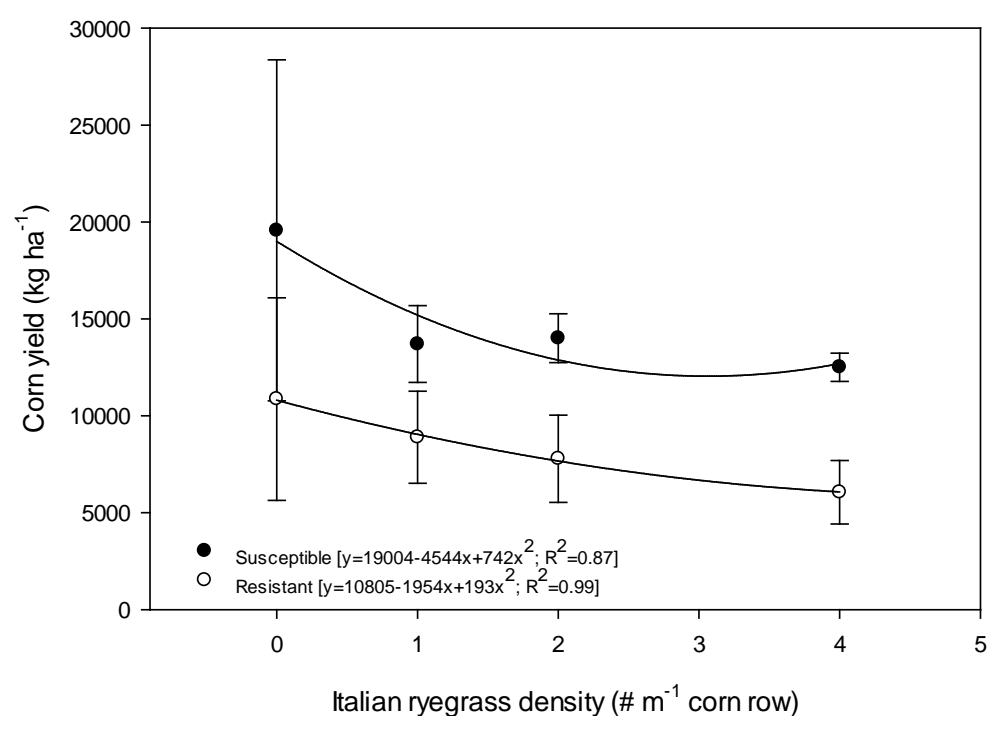

Figure 7. Influence of glyphosate-resistant and -susceptible Italian ryegrass populations on corn yield in 2013.

in corn can occur from fall emerged Italian ryegrass, exemplifying the need for a robust Italian ryegrass management program. Italian ryegrass appears to have an allelopathic effect on corn. Previously, no allelopathic interaction was reported between wheat and Italian ryegrass [18] [19]. However, an allelochemical isolated from decaying Italian ryegrass residue, benzenepropanoic acid, significantly inhibited the elongation of rice seedling shoots [23].

\section{Conclusion}

Continued reliance on glyphosate for controlling fall emerged Italian ryegrass should be avoided by growers of the midsouthern US. Despite having reached a stage beyond active vegetative growth, Italian ryegrass has been demonstrated to severely restrict corn emergence and establishment. Future research should investigate interpopulation competition between GR and GS accessions, effect on other spring planted crops such as cotton, rice, and soybean, and the role of allelopathy of Italian ryegrass in providing a competitive advantage over accompa- 
nying crops and weeds.

\section{Acknowledgements}

This work was supported by the United States Department of Agriculture-Agricultural Research Service (USDA-ARS) project number 6402-21000-050-00D. The technical assistance of Earl Gordon, Efren Ford, Milton Gaston, Jr., and Paige Goodlett is very much appreciated. The author also thanks Mississippi State University for providing chemical inputs and personnel resources.

\section{References}

[1] Bond, J.A., Eubank, T.W., Bond, R.C., Golden, B.R. and Edwards, H.M. (2014) Glyphosate-Resistant Italian Ryegrass (Lolium perenne ssp. multiflorum) Control with Fall-Applied Residual Herbicides. Weed Technology, 28, 361-370. http://dx.doi.org/10.1614/WT-D-13-00149.1

[2] Nandula, V.K., Poston, D.H. and Reddy, K.N. (2009) Seed Germination Differences between Glyphosate-Resistant and -Susceptible Italian Ryegrass Populations. Seed Technology, 31, 123-131.

[3] United States Department of Agriculture Natural Resources Conservation Service (2014) Lolium perenne ssp. multiflorum (Lam.) Husnot. http://plants.usda.gov/core/profile?symbol=LOPEM2

[4] Hafenrichter, A.L., Schwendiman, J.L. and Harris, H.L. (1968) Grasses and Legumes for Soil Conservation in the Pacific Northwest and Great Basin States. In: Agriculture Handbook 339, United States Departments of Agriculture, Soil Conservation Service, Washington DC, 69.

[5] Hall, M.H. (1992) Ryegrass Agronomy Facts 19. The Pennsylvania State College of Agricultural Sciences Cooperative Extension, State College.

[6] Hannaway, D., Fransen, S., Cropper, J., Teel, M., Chaney, M., Griggs, T., Halse, R., Hart, J., Cheeke, P., Hansen, D., Klinger, R. and Lane, W. (1999) Annual Ryegrass (Lolium multiflorum Lam.). http://extension.oregonstate.edu/catalog/html/pnw/pnw501/

[7] Carey, J.H. (1995) Lolium multiflorum. http://www.fs.fed.us/database/feis

[8] Wilken, D.H. (1993) Lolium. In: Hickman, J.C., Ed., The Jepson Manual: Higher Plants of California, University of California Press, Berkeley, 1400.

[9] Appleby, A.P., Olson, P.D. and Colbert, D.R. (1976) Winter Wheat Yield Reduction from Interference by Italian Ryegrass. Agronomy Journal, 68, 463-466. http://dx.doi.org/10.2134/agronj1976.00021962006800030007x

[10] Bell, C.E. (1995) Broccoli (Brassica oleracea var. botrytis) Yield Loss from Italian Ryegrass (Lolium perenne) Interference. Weed Science, 43, 117-120.

[11] Hashem, A., Radosevich, S.R. and Roush, M.L. (1998) Effect of Proximity Factor on Competition between Winter Wheat (Triticum aestivum) and Italian Ryegrass (Lolium multiflorum). Weed Science, 46, 181-190.

[12] Heap (2014) International Survey of Herbicide Resistant Weeds. http://www.weedscience.org/Summary/home.aspx

[13] Taylor, J.M. and Coats, G.E. (1996) Identification of Sulfometuron-Resistant Italian Ryegrass (Lolium multiflorum) Selections. Weed Technology, 10, 943-946.

[14] Perez, A. and Kogan, M. (2003) Glyphosate-Resistant Lolium multiflorum in Chilean Orchards. Weed Research, 43, 12-19. http://dx.doi.org/10.1046/j.1365-3180.2003.00311.x

[15] Perez-Jones, A., Park, K., Colquhoun, J., Mallory-Smith, C. and Shaner, D. (2005) Identification of Glyphosate-Resistant Italian Ryegrass (Lolium multiflorum) in Oregon. Weed Science, 53, 775-779. http://dx.doi.org/10.1614/WS-04-200R.1

[16] Nandula, V.K., Poston, D.H., Eubank, T.W., Koger, C.H. and Reddy, K.N. (2007) Differential Response to Glyphosate in Italian Ryegrass (Lolium multiflorum) Populations from Mississippi. Weed Technology, 21, 477-482. http://dx.doi.org/10.1614/WT-06-168.1

[17] Zablotowicz, R.M., Reddy, K.N., Krutz, L.J., Gordon, R.E., Jackson, R.E. and Price, L.D. (2011) Can Leguminous Cover Crops Partially Replace Nitrogen Fertilization in Mississippi Delta Cotton Production? International Journal of Agronomy, 2011, Article ID: 135097. http://dx.doi.org/10.1155/2011/135097

[18] Stone, M.J., Cralle, H.T., Chandler, J.M., Miller, T.D., Bovey, R.W. and Carson, K.H. (1998) Above- and Belowground Interference of Wheat (Triticum aestivum) by Italian Ryegrass (Lolium multiflorum). Weed Science, 46, 438441.

[19] Cralle, H.T., Fojtasek, T.B., Carson, K.H., Chandler, J.M., Miller, T.D., Senseman, S.E., Bovey, R.W. and Stone, M.J. (2003) Wheat and Italian Ryegrass (Lolium multiflorum) Competition as Affected by Phosphorus Nutrition. Weed Sci- 
ence, 51, 425-429. http://dx.doi.org/10.1614/0043-1745(2003)051[0425:WAIRLM]2.0.CO;2

[20] Liebl, R. and Worsham, A.D. (1987) Interference of Italian Ryegrass (Lolium multiflorum) in Wheat (Triticum aestivum). Weed Science, 35, 819-823.

[21] Appleby, A.P. and Brewster, B.D. (1992) Seedling Arrangement on Winter Wheat (Triticum aestivum) Grain Yield and Interaction with Italian Ryegrass (Lolium multtiflorum). Weed Technology, 6, 820-823.

[22] Kobayashi, R., Tateno, K. and Sato, S. (1997) Yield Decrease of Corn Sown into Italian Ryegrass by Minimum Tillage. http://www.internationalgrasslands.org/files/igc/publications/1997/2-19-069.pdf

[23] Li, G.X., Zeng, R.S., Li, H.J., Yang, Z.Y., Xin, G.R., Yuan, J.G. and Luo, Y. (2008) Allelopathic Effects of Decaying Italian Ryegrass (Lolium multiflorum Lam.) Residues on Rice. Allelopathy Journal, 22, 15-24. 
Scientific Research Publishing (SCIRP) is one of the largest Open Access journal publishers. It is currently publishing more than 200 open access, online, peer-reviewed journals covering a wide range of academic disciplines. SCIRP serves the worldwide academic communities and contributes to the progress and application of science with its publication.

Other selected journals from SCIRP are listed as below. Submit your manuscript to us via either submit@scirp.org or Online Submission Portal.
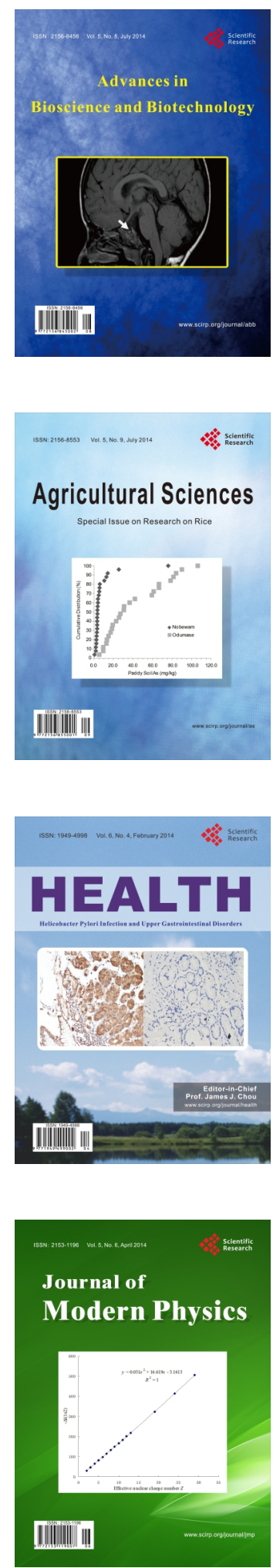
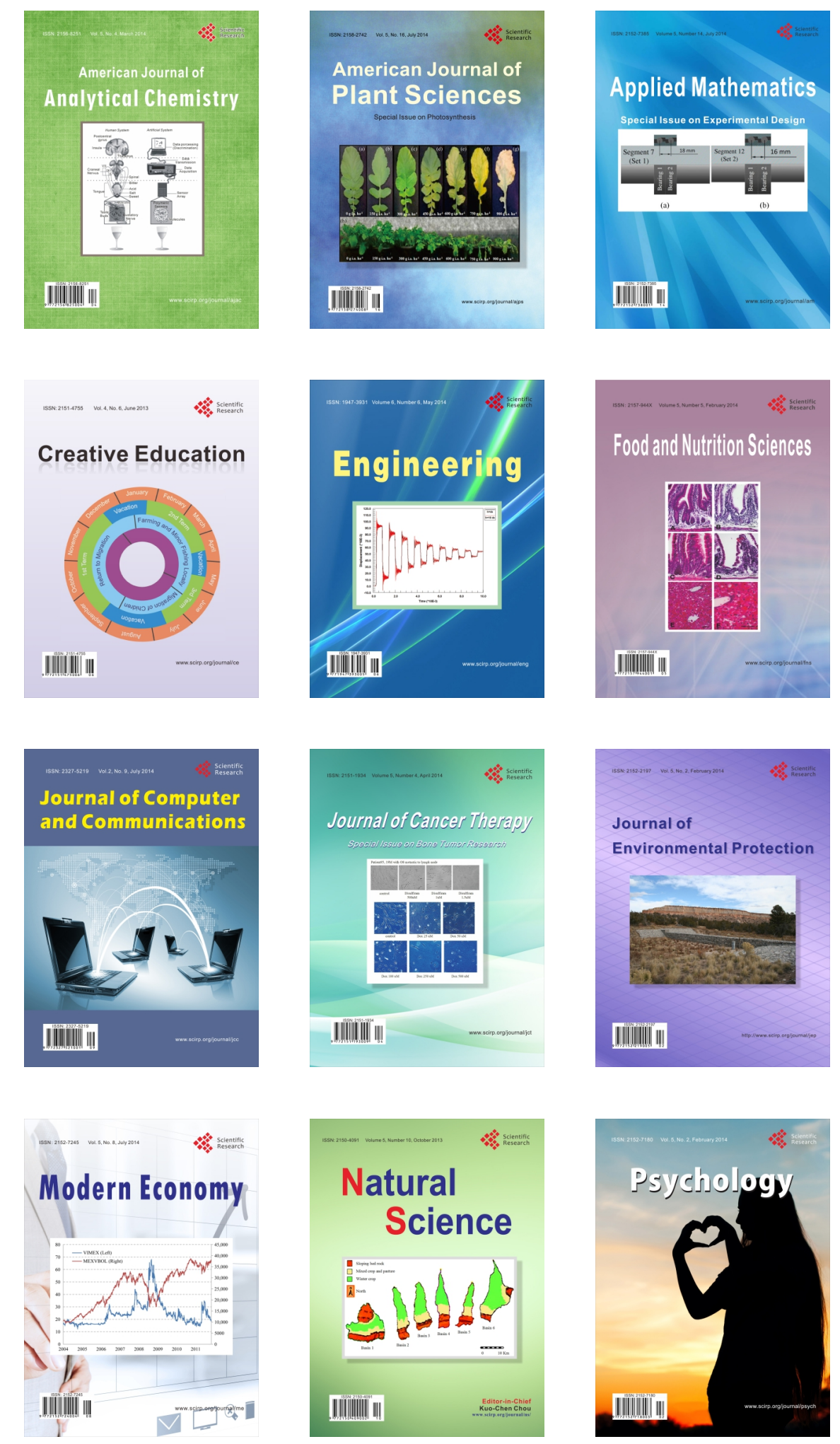